\title{
ГУМОРАЛЬНІ ЗМІНИ У КРОВІ ДОСЛІДЖУВАНИХ ТВАРИН ПРИ ГІПЕРЕРГІЧНОМУ ТИПІ ЗАПАЛЬНОЇ РЕАКЦІЇ ЗА УМОВ ЕКСПЕРИМЕНТАЛЬНОГО ГАСТРОДУОДЕНІТУ
}

Вступ. На сьогодні доведено той фракт, що провідним фрактором розвитку і прогресування різноманітних захворювань є не причина, яка викликала патологічний стан, а порушення, зумовлені зміненими, посиленими чи, навпаки, послабленими імунними процесами в організмі.

Мета дослідження - оцінити гуморальні зміни у крові тварин при гіперергічному типі запальної реакції за умов експериментального гастродуоденіту.

Методи дослідження. Експерименти виконано на щурах масою 180-200 г. В усіх тварин моделювали гострий гастродуоденіт. Гіперергічний тип запальної реакції моделювали шляхом внутрішньом'язового введення пірогеналу на фрізіологічному розчині, нормоергічний - без додаткового введення будь-яких речовин. Для виконання експериментів щурів поділили на 3 групи (по 6 тварин у кожній). Вміст імуноглобулінів (Ig) класів A, M, G у сироватці крові визначали за методом К. Ф. Чернушенко. Обробку результатів виконували у відділі системних статистичних досліджень у програмному пакеті Statsoft STATISTICA.

Результати й обговорення. У щурів з гіперергічним типом запальної реакції рівень циркулюючих імунних комплексів (ЦІК), порівняно з контролем, був вищим: на 7-му добу дослідження - на $84 \%(p<0,05)$, на 10-ту - на 89,4 \% (p<0,05). При порівнюванні показників тварин цієї групи з показниками щурів із нормоергічним типом запальної реакції виявлено, що вміст ЦІК був більшим: на 7-му добу дослідження - на 7,3 \% (p<0,05), на 10-ту - на 6,3 \% ( $p<0,05)$. У щурів з гіперергічним типом запальної реакції рівень імуноглобулінів усіх трьох класів був вищим: IgA на 7-му добу дослідження - на 76 \% (p<0,05), на 10-mу - на 78,2 \% (p<0,05); IgM на 7-му добу дослідження - на 24,4 \% (p<0,05), на 10-mу - на 23,4 \% (p<0,05); IgG на 7-му добу дослідження - на 69 \% (p<0,05), на 10-ту - на 70,1\% (p<0,05). Вміст імуноглобулінів класів A, M, G та циркулюючих імунних комплексів у сироватці крові тварин усіх груп на 10-ту добу дослідження збільшувався.

Висновок. Найбільш значні зміни імунологічних показників виявлено у тварин з гіперергічним типом запальної реакції, а зміни гуморального імунітету супроводжувалися зростанням рівня імуноглобулінів класів A, M, G та циркулюючих імунних комплексів упродовж 10-ти діб.

КЛЮЧОВІ СЛОВА: гастродуоденіт; тип запальної реакції; імуноглобуліни класів А, M, G; циркулюючі імунні комплекси.

ВСТУП. На сьогодні доведено той фракт, що провідним фрактором розвитку і прогресування різноманітних захворювань є не причина, яка викликала патологічний стан, а порушення, зумовлені зміненими, посиленими чи, навпаки, послабленими імунними процесами в організмі. Імунологічні порушення при захворюванні на гастродуоденіт характеризуються порушеннями взаємодії чинників неспецифічної резистентності організму, пригніченням клітинного, гуморального, а також місцевого імунітету. В літературних джерелах описано зміни показників гуморального імунітету в щурів із запальними захворюваннями слизової оболонки органів порожнини рота, в результаті запального процесу підвищився рівень імуноглобулінів (Ig) та циркулюючих (c) В. І. Бондарчук, 2018. імунних комплексів (ЦІК) у сироватці крові. Зростання їх показників характеризували як дисбаланс гуморальної ланки імунітету, що $€$ важливим не тільки для діагностики, але й для прогнозу перебігу захворювання, та свідчить про надмірну активність В-лімсроцитів 3 можливим розвитком реакції гіперчутливості [1-5]. Тому вказана проблематика є важливою, актуальною і вимагає свого вирішення.

Мета дослідження - оцінити гуморальні зміни у крові тварин при гіперергічному типі запальної реакції за умов експериментального гастродуоденіту.

МЕТОДИ ДОСЛІДЖЕННЯ. Експерименти виконано на щурах масою 180-200 г, яких утримували у звичайних умовах на стандартному 
раціоні віварію відповідно до Науково-практичних рекомендацій з утримання лабораторних тварин та роботи з ними [6] і положень Європейської конвенції про захист хребетних тварин, що використовуються для дослідних та інших наукових цілей (Страсбург, 1986), а також Загальних етичних принципів експериментів на тваринах [7]. В усіх тварин протягом 7-ми діб моделювали гострий гастродуоденіт, вводячи у шлунок за допомогою зонда 0,25 мл $10 \% \mathrm{C}_{2} \mathrm{H}_{5} \mathrm{OH}$, а через 5 хв - 0,5 мл 1,25\% HCl [8]. Гіперергічний тип запальної реакції (ТЗР) моделювали шляхом внутрішньом'язового введення пірогеналу (НДІЕМ ім. М. Ф. Гамалеї РАМН, Росія) на фрізіологічному розчині (5 МПД на одного щура) за день до моделювання гастродуоденіту і щоденно протягом 7-ми діб [9]. Нормоергічний ТЗР розвивався у тварин з експериментальним гастродуоденітом без додаткового введення будьяких речовин. Для виконання експериментів щурів поділили на 3 групи (по 6 тварин у кожній): 1-ша - інтактні тварини (контроль); 2-га - щури 3 нормоергічним ТЗР; 3-тя - тварини з гіперергічним ТЗР. Тварин виводили з експериментів шляхом швидкої декапітації під тіопентал-натрієвим наркозом, вводячи внутрішньочеревно $5 \%$ розчин тіопентал-натрію з розрахунку 1 мл на 100 г маси тіла тварин на 7-му та 10-ту доби після моделювання гострого гастродуоденіту. Вміст імуноглобулінів класів A, M, G у сироватці крові визначали за методом К. Ф. Чернушенко [10]. Для досліджень використовували напівавтоматичний біохімічний аналізатор "Humalyzer 2000" і набір реактивів фрірми "Human" (Німеччина). Концентрацію імуноглобулінів виражали в г/л [11]. Обробку результатів виконували у відділі системних статистичних досліджень Тернопільського державного медичного університету імені І. Я. Горбачевського в програмному пакеті Statsoft STATISTICA. Для обробки числових величин і об'єктивної оцінки ступеня достовірності результатів досліджень використовували варіаційно-статистичний метод аналізу даних. Визначали середню величину (M), ї̈ похибку (m). Достовірність різниці значень між незалежними кількісними величинами встановлювали за допомогою критерію Манна - Уїтні. Результати вважали статистично вірогідними при $p<0,05$. Усі вимірювання та дослідження проводили 3 використанням засобів вимірювальної техніки, які пройшли метрологічну повірку, та допоміжного обладнання, яке було проатестовано.

РЕЗУЛЬТАТИ Й ОБГОВОРЕННЯ. ОДНИМ 3 індикаторів стану імунної системи організму $€$ вміст ЦІК у сироватці крові. У щурів з гіперергічним ТЗР рівень ЦІК, порівняно з контролем, був вищим: на 7-му добу дослідження - на $84 \%$ $(p<0,05)$, на 10-ту - на 89,4\% $(p<0,05)$. При порівнюванні показників тварин цієї групи з показниками щурів із нормоергічним ТЗР виявлено, що вміст ЦІК був більшим: на 7-му добу дослідження - на 7,3 \% (p<0,05), на 10-ту - на 6,3\% $(p<0,05)$. Рівень імуноглобулінів класів A, M, G був вищим відносно контролю у тварин усіх груп та в різні терміни дослідження. У щурів з гіперергічним ТЗР він був більшим: IgA на 7-му добу дослідження - на $76 \%(p<0,05)$, на 10-ту - на $78,2 \%(p<0,05)$; IgM на 7-му добу дослідження на 24,4 \% (p<0,05), на 10-ту - на 23,4 \% ( $<<0,05)$; IgG на 7-му добу дослідження - на $69 \%(\mathrm{p}<0,05)$, на 10-ту - на 70,1 \% $(p<0,05)$. При порівнюванні показників щурів цієї групи з показниками тварин 3 нормоергічним ТЗР виявлено, що рівень IgA був вищим: на 7-му добу дослідження - на 9,1 \% $(p<0,05)$, на 10-ту - на 8,9\% $(p<0,05)$.

У тварин з нормоергічним ТЗР вміст ЦІК був вищим відносно контролю: на 7-му добу дослідження - на 71,3\% (p<0,05), на 10-ту - на $78 \%$ $(p<0,05)$. Порівняно зі щурами з гіперергічним ТЗР рівень ЦІК був нижчим: на 7-му добу дослідження - на 6,8\% $(p<0,05)$, на 10-ту - на 5,9\% $(p<0,05)$.

У тварин 3 нормоергічним ТЗР, порівняно 3 контролем, рівень імуноглобулінів усіх трьох класів був вищим: IgA на 7-му добу дослідження - на $61,3 \%(p<0,05)$, на 10-ту - на 63,6 \% $(p<0,05) ;$ IgM на 7-му добу дослідження - на $20,5 \%(p<0,05)$, на 10-ту - на $21 \%(p<0,05) ; \lg G$ на 7-му добу дослідження - на 67,9 \% $(p<0,05)$, на $10-т у-$ на $66,6 \%(p<0,05)$. Порівняно $з$ групою щурів з гіперергічним ТЗР варто відмітити зниження рівня IgA: на 7-му добу дослідження - на $8,3 \%(p<0,05)$, на 10-ту - на 8,1 \% ( $<<0,05)$.

У групі тварин з гіперергічним ТЗР вміст IgM на 7-му добу дослідження був найбільшим $(0,938 \pm 0,014)$ г/л, група щурів 3 нормоергічним ТЗР за показниками IgM на 10-ту добу дослідження займала проміжне місце - $(0,913 \pm 0,003)$ г/л. У групі тварин 3 гіперергічним ТЗР рівень IgG на 10-ту добу дослідження був найвищим $(1,433 \pm 0,002)$ г/л, група щурів 3 нормоергічним T3P за вмістом IgG на 7-му добу дослідження займала проміжне місце - $(1,414 \pm 0,003)$ г/л.

Таким чином, у результаті проведених досліджень було виявлено, що рівень імуноглобулінів класів A, M, G у сироватці крові тварин усіх груп підвищувався (рис. 1) порівняно з контролем.

За результатами досліджень, максимальний вміст ЦІК у сироватці крові тварин з різними ТЗР відзначали на 10-ту добу експерименту. В щурів 3 гіперергічним ТЗР він був найбільшим $(122,500 \pm 0,847)$ ум. од., у тварин 3 нормоергічним ТЗР вказаний показник займав проміжне місце - $(115,167 \pm 1,195)$ ум. од. (рис. 2). 


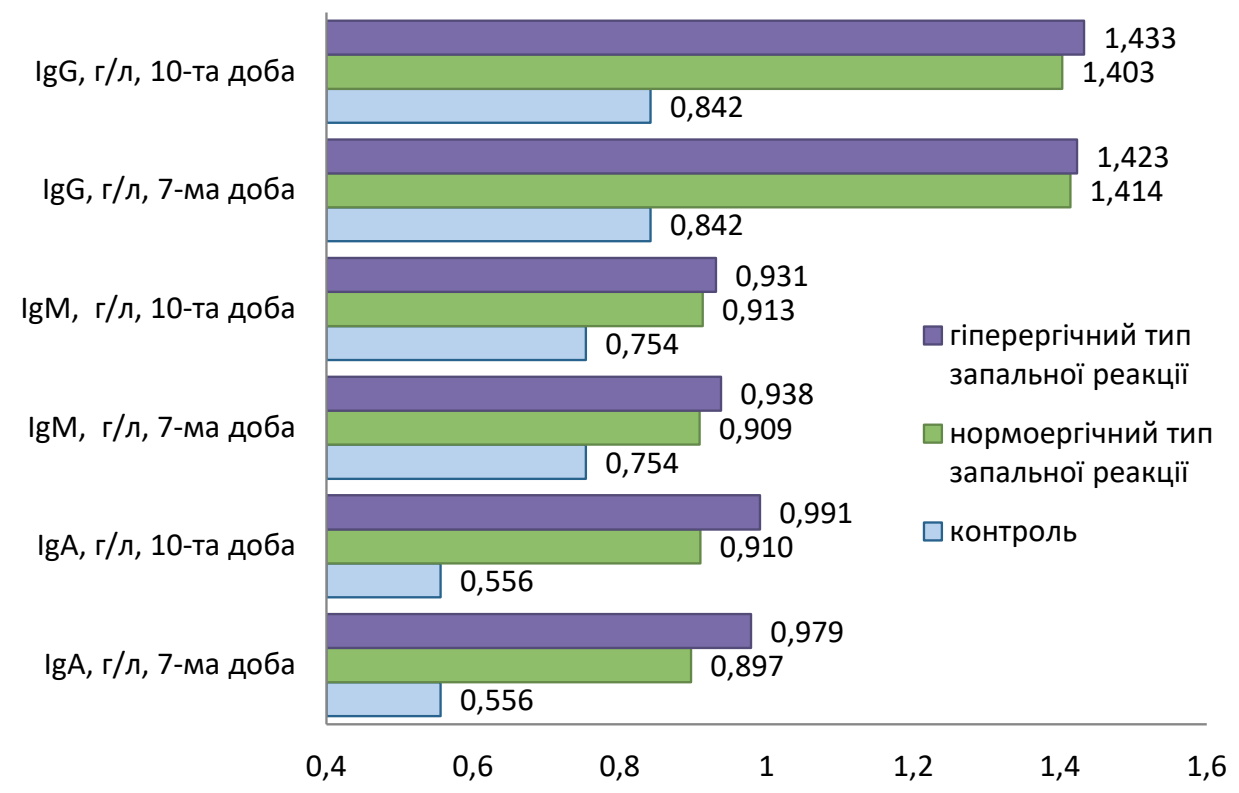

Рис. 1. Зміна рівня імуноглобулінів класів A, M, G у сироватці крові тварин досліджуваних груп.

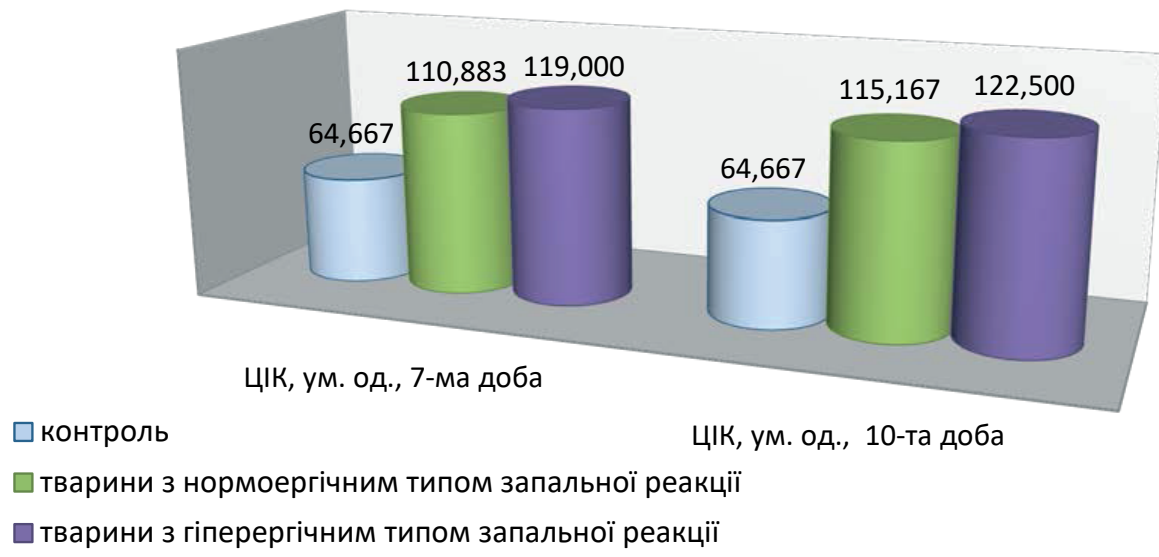

Рис. 2. Зміна вмісту циркулюючих імунних комплексів у сироватці крові тварин досліджуваних груп.

На тлі вищезазначених змін було встановлено, що ТЗР істотно залежить від особливостей перебудови гуморальних імунологічних процесів, а збільшення вмісту ЦІК характеризує дисбаланс гуморальної ланки імунітету.

\section{СПИСОК ЛІТЕРАТУРИ}

1. Авдєєв О. В. Клініко-патогенетичні основи розвитку та лікування запальних та дистрофічно-запальних захворювань пародонта при різній реактивності організму : дис. ... доктора мед. наук : 14.01.22 / Авдєєв Олександр Володимирович. - Львів, 2013. - 342 с.

2. Атаман О. В. Запалення / О. В. Атаман. - Суми : Вид-во СумДУ, 2006. - 66 с.

3. Бондарчук В. І. Зміна показників гуморального імунітету при різних типах запальної реакції у тварин із гастродуоденітом / В. І. Бондарчук // Мед. та клініч. хімія. - 2016. - 18, № 3 (68). - С. 86-91.
ВИСНОВОК. Найбільш значні зміни імунологічних показників виявлено у тварин з гіперергічним типом запальної реакції, а зміни гуморального імунітету супроводжувалися зростанням рівня імуноглобулінів класів A, M, G та циркулюючих імунних комплексів упродовж 10-ти діб.

4. Факторы местной резистентности и иммунологической реактивности полости рта. Способы их клинико-лабораторной оценки (обзор литературы) / Л. М. Цепов, Л. Ю. Орехова, А. И. Николаев, Е. А. Михеева // Пародонтология. - 2005. - № 3 (36). - С. 3-9.

5. Яворський В. В. Імунологічна реактивність при систематичних донаціях плазми : автореф. дис. на здобуття наук. ступеня канд. мед. наук / В. В. Яворський. - 2014. - 24 с.

6. Науково-практичні рекомендації з утримання лабораторних тварин та роботи з ними / Ю.М.Ко- 
жем'якін, О. С. Хромов, М. А. Філоненко, Г. А. Сайфетдінова. - К. : Авіцена, 2002. - 156 с.

7. Резніков О. Г. Загальні етичні принципи експериментів на тваринах. Перший національний конгрес з біоетики / О. Г. Резніков // Ендокринологія. - 2003. № 1 (8). - С. 142-145.

8. Пат. 98021 Україна, МПК G09B23/28, G01N23/48. Спосіб моделювання запальних процесів слизової оболонки порожнини рота / Мисула Н. І., Авдєєв О. В. ; заявник і патентовласник Терноп. держ. мед. ун-т імені І. Я. Горбачевського. - № u2014 12673 ; заявл. 25.11.14 ; опубл. 10.04.15, Бюл. № 7.

\section{REFERENCES}

1. Avdieiev, O.V. (2013). Kliniko-patohenetychni osnovy rozvytku ta likuvannia zapalnykh ta dystrofichnozapalnykh zakhvoriuvan parodonta pry riznii reaktyvnosti orhanizmu [Clinical and pathogenetic bases of development and treatment of inflammatory and dystrophicinflammatory diseases of periodontal disease at different reaction of organism]. Doctor's thesis. Lviv [in Ukrainian].

2. Ataman, O.V. (2006). Zapalennia [Inflammation]. Sumy [in Ukrainian].

3. Bondarchuk, V.I. (2016). Zmina pokaznykiv humoralnoho imunitetu pry riznykh typakh zapalnoi reaktsii u tvaryn iz hastroduodenitom [Changes in indices of humoral immunity in different types of inflammatory reaction in animals with gastroduodenitis]. Medychna ta klinichna khimiia - Medical and Clinical Chemistry, 18 (3), 86-91 [in Ukrainian].

4. Tsepov, L.M., Orekhova, L.Yu., Nikolayev, A.I., \& Mikheyeva, E.A. (2005). Faktory mestnoi rezistentnosti i immunologicheskoy reaktivnosti polosti rta. Sposoby ikh kliniko-laboratornoy otsenki (obzor literatury) [Factors of local resistance and immunological reactivity of the oral cavity. Methods of their clinical and laboratory assessment (review of literature)]. Parodontologiya-Periodontology, 3 (36), 3-9 [in Russian].

5. Yavorskyi, V.V. (2014). Imunolohichna reaktyvnist pry systematychnykh donatsiiakh plazmy [Immunological reactivity at systematic plasma donations]. Candidate's Extended abstract. Kharkiv [in Ukrainian].
9. Пат. 66298 Україна, МПК А61К 39/104 (2006.01); G09B 23/28 (2006.01). Спосіб моделювання пародонтиту / Авдєєв О. В. ; заявник і патентовласник Терноп. держ. мед. ун-т імені І. Я. Горбачевського. № u201108090 ; заявл. 29.06.11 ; опубл. 26.12.11, Бюл. № 24.

10. Чернушенко Е. Ф. Иммунологические методы исследования в клинике / Е. Ф. Чернушенко, Л. С. Когосова. - К. : Здоров'я, 1978. - 159 с.

11. Гриневич Ю. А. Определение иммунных комплексов в крови онкологических больных / Ю. А. Гриневич, А. М. Алферов // Лаб. дело. - 1981. - № 8. C. 493-495.

6. Kozhemiakin, Yu.M., Khromova, O.S., \& Filonenko, M.A. (2002). Naukovo-praktychni rekomendatsii z utrymannia laboratornykh tvaryn ta robota z nymy [Scientific and practical recommendations for the maintenance of laboratory animals and work with them]. Kyiv: Avitsena [in Ukrainian].

7. Reznikov, O.H. (2003). Zahalni etychni pryntsypy eksperymentiv na tvarynakh. Pershyi natsionalnyi konhres z bioetyky [General ethical principles of experiments on animals. First National Congress on Bioethics]. Endokrynolohiia - Endocrinology. 1 (8), 142-145 [in Ukrainian].

8. Mysula, N.I., \& Avdieiev, O.V. (2015). Sposib modeliuvannia zapalnykh protsesiv slyzovoi obolonky porozhnyny rota [Method of modeling inflammatory processes of the mucous membrane of the oral cavity]. Patent Ukraina, № u201010071 [in Ukrainian].

9. Avdieiev, O. V. (2011). Sposib modeliuvannia parodontytu [Method for periodontitis modeling]. Patent Ukraina, № u201108090 [in Ukrainian].

10. Chernushenko, E.F., \& Kogosova, L.S. (1978). Immunologicheskie metody issledovaniya $v$ klinike [Immunological methods of research in a clinic]. Kyiv: Zdorovia [in Russian].

11. Grinevich, Yu.A., \& Alferov, A.M. (1981). Opredelenie immunnykh kompleksov $v$ krovi onkologicheskikh bolnykh [Definition of immune complexes in the blood of cancer patients]. Laboratornoye delo - Laboratory Business, 8, 493-495 [in Russian].

\section{ГУМОРАЛЬНЫЕ ИЗМЕНЕНИЯ В КРОВИ ИССЛЕДУЕМЫХ ЖИВОТНЫХ ПРИ ГИПЕРЕРГИЧЕСКОМ ТИПЕ ВОСПАЛИТЕЛЬНОЙ РЕАКЦИИ В УСЛОВИЯХ ЭКСПЕРИМЕНТАЛЬНОГО ГАСТРОДУОДЕНИТА}

\section{Резюме}

Вступление. На сегодня доказан тот факт, что ведущим фрактором развития и прогрессирования различных заболеваний является не причина, вызвавшая патологическое состояние, а нарушения, обусловленные изменившимися, усиленными или, наоборот, ослабленными иммунными процессами в организме.

Цель исследования - оценить гуморальные изменения в крови животных при гиперергическом типе воспалительной реакции в условиях экспериментального гастродуоденита. 
Методы исследования. Эксперименты выполнены на крысах массой 180-200 г. У всех животных моделировали острый гастродуоденит. Гиперергический тип воспалительной реакции моделировали путем внутримышечного введения пирогенала на фризиологическом растворе, нормоергичический - без дополнительного введения любых веществ. Для выполнения экспериментов крыс разделили на 3 группы (по 6 животных в каждой). Содержание иммуноглобулинов (Ig) класов A, M, G в сыворотке крови определяли по методу Е. Ф. Чернушенко. Обработку результатов выполняли в отделе системных статистических исследований в программном пакете Statsoft STATISTICA.

Результаты и обсуждение. У крыс с гиперергическим типом воспалительной реакции уровень циркулирующих иммунных комплексов (ЦИК), по сравнению с контролем, был выше: на 7-е сутки исследования - на 84 \% (p<0,05), на 10-е - на 89,4 \% $(p<0,05)$. При сравнивании показателей животных этой группы с показателями крыс нормоергическим типом воспалительной реакции обнаружено, что содержание ЦИк было больше: на 7-е сутки исследования - на 7,3 \% (p<0,05), на 10-е - на 6,3 \% (p<0,05). У крыс с гиперергическим типом воспалительной реакции уровень иммуноглобулинов всех трех классов был выше: IgA на 7-е сутки исследования - на 76 \% (p<0,05), на 10-е - на 78,2 \% (p<0,05); IgM на 7-е сутки исследования - на 24,4 \% (p<0,05), на 10-е - на 23,4 \% (p<0,05); IgG на 7-е сутки исследования - на $69 \%$ $(p<0,05)$, на 10-е - на 70,1 \% (p<0,05). Содержание иммуноглобулинов классов A, M, G и циркулирующих иммунных комплексов в сыворотке крови животных всех групп на 10-е сутки исследования увеличивался.

Вывод. Наиболее значительные изменения иммунологических показателей выявлено у животных с гиперергическим типом воспалительной реакции, а изменения гуморального иммунитета сопровождались возрастанием уровня иммуноглобулинов классов $A, M, G$ и циркулирующих имунных комплексов в течение 10-ти суток.

КЛЮЧЕВЫЕ СЛОВА: гастродуоденит; тип воспалительной реакции; иммуноглобулины классов A, M, G; циркулирующие иммунные комплексы.

\section{I. Bondarchuk \\ I. HORBACHEVSKY TERNOPIL STATE MEDICAL UNIVERSITY}

\section{GUMORAL CHANGES IN BLOOD OF RESEARCHED ANIMALS IN THE GYPEREGIC TYPE OF INFLAMMATORY REACTION UNDER CONDITIONS OF EXPERIMENTAL GASTRODUODENITIS}

Summary
Introduction. To date, it is proved that the leading factor in the development and progression of various diseases is not the source that caused the pathological condition, but violations caused by altered, strengthened or vice versa, weakened immune processes in the body.

The aim of the study - to estimate humoral changes in the blood of animals with hyperergic type of inflammatory reaction under experimental gastroduodenitis.

Research Methods. Experiments were performed on rats weighing 180-200 g. In all animals, acute gastroduodenitis was modeled. Hyperergic type of inflammatory response was modeled by intramuscular administration of pyrogenal in a physiological solution. Normoergic type of inflammatory response - without the additional administration of any substances. Animals were divided into 3 groups (6 animals per group) for the experiment. Determination of Ig A, M, G in blood serum was carried out using the Chernushenko E. F. method. The results were processed in the department of system statistical research in the software package Statsoft STATISTICA.

Results and Discussion. In animals with hyperergic type of inflammatory response, the content of circulating immune complexes in comparison with control was higher at the $7^{\text {th }}$ day of the study - by $84 \%(p<0.05)$, by the $10^{\text {th }}$ day - by $89.4 \%(p<0.05)$. Comparing the indices of the same group of animals with normoergic type of inflammatory response found that the content of the circulating immune complexes was higher at the $7^{\text {th }}$ day of the study - by $7.3 \%(p<0.05)$, at the $10^{\text {th }}$ day - by $6.3 \%(p<0.05)$. In rats with hyperergic type of inflammatory response, the level of immunoglobulins of all three classes was higher at the $7^{\text {th }}$ day of the study - by $76 \%(p<0.05)$, at the $10^{\text {th }}$ day by $78.2 \%(p<0.05)$; Ig M level was higher at the $7^{\text {th }}$ day of the study - by $24.4 \%(p<0.05)$, for the $10^{\text {th }}$ day - by $23.4 \%$ ( $p<0.05)$; IgG level was higher at the $7^{\text {th }}$ day of the study - by $69 \%(p<0.05)$, for the $10^{\text {th }}$ day - by $70.1 \%$ $(p<0.05)$. The levels of $\lg A, M, G$, and the content of circulating immune complexes for the 10th day of serum blood test in all animal groups were elevated.

Conclusion. The most significant changes in immunological parameters were found in animals with hyperergic type of inflammatory response, and changes in humoral immunity were accompanied by an increase level in immunoglobulins A, M, G classes and circulating immune complexes for 10 days.

KEY WORDS: gastroduodenitis; type of inflammatory reaction; immunoglobulins of classes A, M, G; circulating immune complexes.

Отримано 31.10 .18

Адреса для листування: В. І. Боднарчук, Тернопільський державний медичний університет імені І. Я. Горбачевського, майдан Волі, 1, Тернопіль, 46001, Україна, e-mail: bondarchykvi@tdmu.edu.ua. 